\title{
Дослідження морфологічних ознак видів роду Echinacea (L.) Moench. при інтродукції в умови Кременецького ботанічного саду
}

\section{Людмила Кубінська, Микола Кубінський}

Кременецький ботанічний сад, Кременець, Україна

Адреса для листування: nikkubinskiy@ukr.net

Отримано: 30.01.19; прийнято до друку: 12.03.19; опубліковано: 28.06.19

Резюме. У статті висвітлено питання інтродукції видів роду Echinacea в умови Кременецького ботанічного саду. Мета роботи - комплексне дослідження морфобіологічних особливостей видів роду Echinacea при інтродукції в умови Кременецького ботанічного саду. Завдання досліджень - установити біометричні та морфометричні показники пагонів, листків і цвітіння генеративних особин різних видів роду Echinacea. Наведено характеристику природно-кліматичних умов регіону інтродукції. Подано ботанічні описи трьох найбільш поширених видів роду, здійснено аналіз біометричних параметрів пагонів. Установлено, що молоді генеративні рослини E. paradoxa на третій рік вегетації мають меншу висоту, діаметр стебла та кількість генеративних пагонів на рослину з 1-м або 2 суцвіттями на пагоні, порівняно з іншими видами. Проаналізовано морфометричні параметри листків різних видів Ехінацеї, установлено, що до ознак видової мінливості рослин роду Echinacea можна віднести висоту рослин, діаметр стебла, довжину черешка. Водночас ширина листкової пластинки не $\epsilon$ чіткою видовою ознакою. За даними фенологічних спостережень установлено, що найпершою в умовах Кременецького ботанічного саду зацвітає E. paradoxa, найпізніше - E. purpurea. Тривалість цвітіння найдовша в E. purpurea. Найбільш інтенсивно цвітіння проходить в E. purpurea.

Ключові слова: біометричні показники, видова ознака, генеративні особини, морфометричні параметри.

\section{Study of Morphological Features of Species of the Genus Echinacea (L.) Moench. on Induction Into the Conditions of Kremenets' Botanical Garden}

\section{Lyudmyla Kubinska, Mykola Kubinskiy}

Kremenets botanical garden, Kremenets, Ukraine

Correspondence: nikkubinskiy@ukr.net

\begin{abstract}
The article covers the introduction of species of the genus Echinacea in the conditions of the Kremenets' Botanical Garden. The purpose of the work was to study the morphological and biological features of the genus Echinacea at the introduction into the conditions of the Kremenets' Botanical Garden. The objectives of the research were to establish biometric and morphometric indices of shoots, leaves and flowering of generative individuals of different species of the genus Echinacea. The description of the natural and climatic conditions of introduction is given. The botanical descriptions of the three most common types of the genus are given, the analysis of the biometric parameters of the shoots is given. It has been established that young generative plants E. paradoxa have a lower height and diameter of the stem in the third year of vegetation, and a smaller number of generative shoots per plant with 1 or 2 inflorescences on the shoal, as compared to other species. Morphometric parameters of leaves of different species of Echinacea were analyzed, and it was established that the height of plants, diameter of the stem, length of the petiole can be attributed to the signs of species variability of the genera Echinacea. At the same time, the width of the leaf blade is not a distinct feature. According to the phenological observations, it has been established that E. paradoxa, the earliest E. purpurea, blooms under the conditions of the Kremenets' Botanical Garden. The duration of flowering is the longest for E. purpurea. The most intensive flowering is specific for in E. purpurea.
\end{abstract}

Key words: biometric indices, species characteristic, generative individuals, morphometric parameters. 
Lesia Ukrainka Eastern European National University Scientific Bulletin Series:

Biological Sciences, 2019, 3 (387)

Вступ

Ботанічні сади, дендропарки, дендрарії України здавна займаються інтродукцією та акліматизацією видів флори задля максимально можливого відтворення різноманіття рослин та введення в культуру, упровадження у виробництво.

Нині відзначено помітне зростання попиту на лікарські засоби рослинного походження, а отже, і на лікарську рослинну сировину. Відтак вирощування лікарських культур $\epsilon$ досить актуальним. Т. І. Деревінська, 1997 та Т. А. Журавель, 2000 відзначають перспективність рослин із роду Ехінацея для впровадження у фітоценози та використання у фітомедицині $[2,3]$.

До роду ехінацея (Echinacea (L.) Moench) iз родини айстрових (Asteraceae) належать дев'ять видів, які в дикорослому стані поширені в східній і центральній частинах Північної Америки, відомі в культурі з XVII ст. Серед них найширше застосування в медицині мають три види: ехінацея пурпурова (E. purpurea (L.) Moench), Ехінацея вузьколиста (E. angustifolia DC.) та ехінацея бліда (E. Pallida Nutt.).

За даними В. Н. Самородова та В. С. Поспелова (1999) [9], у промислових масштабах Echinacea культивується в північно-західних штатах Америки, Західній Канаді, Південній Африці, Австралії, Новій Зеландії, Європі. E. purpurea (L.) Moench $€$ цінним інтродуцентом в Україні та належить до багатотоннажних культивованих видів. Нині використовують понад 300 лікарських препаратів із різних видів роду Echinacea. Лікують ними понад 70 різних захворювань. Молоді листки додають до салатів. Крім того, ця культура є декоративною, медоносною, кормовою та ефіроолійною рослиною. Види роду Ехінацея $€$ економічно вигідною й корисною культурою для впровадження в сівозміну $[8,9]$.

\section{Матеріали та методи досліджень}

Дослідження проводили у 2016-2018 рр. на базі колекції лікарських рослин Кременецького ботанічного саду. Дослідні ділянки розміщені в науковій зоні, в урочищі Калинівка.

Вивчали генеративні рослини трьох видів роду Echinaceae: E. purpure (L) Moench, E. pallida (Nutt) Nutt, E. paradoxa (J. B. S. Norton) Britt., - які інтродуковані в умови Кременецького ботанічного саду. Насіння отримано внаслідок делектусного обміну з Дослідної станції лікарських рослин Березоточчя та ботанічного саду м. Прага.
Мета роботи - комплексне дослідження морфобіологічних особливостей окремих видів роду Echinacea при інтродукції в умови Кременецького ботанічного саду.

Територія Кременецьких гір розміщена на кордоні двох кліматичних провінцій західноєвропейської 3 вологим і помірно теплим кліматом та східноконтинентальної 3 холодним континентальним кліматом: улітку на території переважають північно-західні вітри, які пом'якшують температуру повітря в цей період, а взимку холодні вітри азіатського антициклону досягають Кременецьких гір уже значно ослабленими. Загалом, як зазначено в Проекті організації території Кременецького ботанічного саду, від 2004 р. клімат Кременецьких гір (порівнянно 3 кліматом східний областей України) характеризується більш м'якою зимою, не жарким літом i значною кількістю опадів [6].

Зима на Кременецьких горах розпочинається 3 другої половини листопада й триває до середини березня. Середньозимові температури коливаються від $-2,7$ до - $4,8^{\circ} \mathrm{C}$. Грунт промерзає на глибину 40-60 см. Узимку часто бувають відлиги. Середньорічна температура повітря в районі близько $+7,5^{\circ} \mathrm{C}$; у січні $-4,5^{\circ} \mathrm{C}$, липні $-+18,5^{\circ} \mathrm{C}[6]$.

Найбільш холодним місяцем $є$ січень, найбільш теплим - липень. Танення снігу в середньому розпочинається 13 лютого, а закінчується 13 березня й продовжується 28 днів. Найбільш рання дата танення снігу та його закінчення - 9 січня й 13 лютого, найбільш пізне - 10 березня i 5 квітня. Характерними $є$ пізні весняні та ранні осінні заморозки. Вегетаційний період розпочинається в першій декаді квітня й продовжується до останніх днів жовтня або початку листопада, тобто в середньому становить 205-209 днів. Сума температур - від $5^{\circ} \mathrm{C}$ і вище рівна $2770^{\circ}$ [6].

Найбільша кількість опадів випадає в літні місяці - до 260-265 мм, а протягом вегетаційного періоду - 250-470 мм. Узимку опадів у 2,5-3, а весною й восени - в 1,5 раза менше, ніж улітку. Засух майже не трапляється. Восени, узимку та навесні опади більш довгі й інтенсивні, улітку - навпаки, часто бувають короткочасні грози, час від часу випадає град. Середньорічний показник відносної вологості повітря досягає 70-75\%.

Грунти району досліджень сірі й темно-сірі 3 незначним гумусовим горизонтом, за механічним складом наближені до суглинків. Проведений аналіз грунту на $\mathrm{pH}$, який 
становить 6,0. Він підтвердив слабокислу реакцію грунту на ділянках розміщення колекцій [6].

Морфологічні ознаки вивчали в рослин місцевої репродукції. Опис листової пластинки проводили згідно з роботами 3. Т. Артюшенко, 1990, С. М. Зимана, $2012[1,5]$.

Під час оцінювання інтенсивності приростів та обліку параметрів листкової пластини й стебла користувалися методичними рекомендаціями Г. Н. Зайцева, 1984 [4].

Вивчаючи біологію цвітіння, використовували методику Самородова В. Н., 1999 [9]. Тривалість цвітіння окремих квітів і суцвіть визначали за допомогою щоденних візуальних спостережень.

\section{Результати досліджень}

Висота рослин E. purpurea досягає 50100 см. Стебло пряме, ребристе, опушене жорсткими волосками. Суцвіття - верхівкові кошики: квітки трубчасті, променеві та язичкові - стерильні, віночок пурпуровий (рис. 1). Розеткові листки довгасті, яйцеподібні, довгочерешкові. У верхній частині стебла їх кількість поступово зменшується, розміщення листків чергове. Черешкові листки яйцеподібноланцетні.

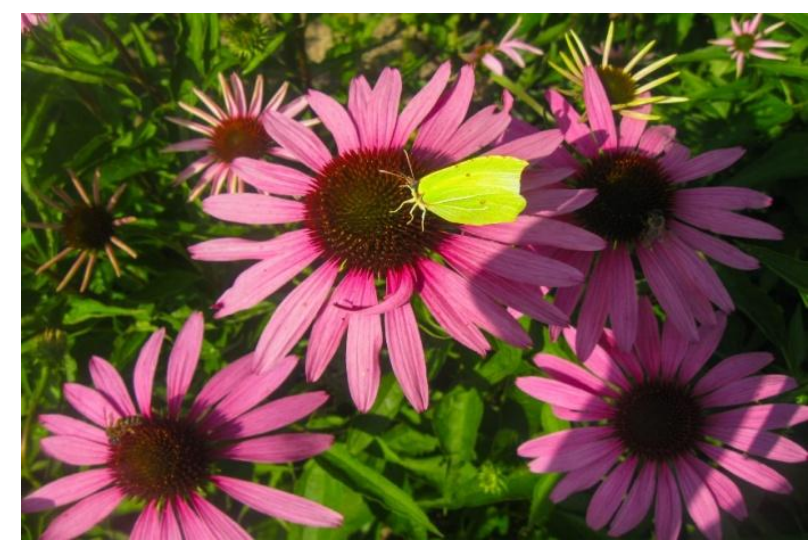

Рис. 1. Цвітіння E. purpurea

Рослини E. pallida досягають висоти 64100 см. Стебло зелене, опушене, ребристе. Суцвіття конусоподібні, поодинокі, великі. Язичкові квітки двозубчасті, безплідні. Трубчасті квітки двостатеві, із п'ятизубчастим, трубчастим, дзвоникоподібним віночком (рис. 2). Стеблові листки розміщені в нижній частині стебла. Прикореневі листки довгочерешкові, ланцетної форми, із зубчастим краєм. Стеблові листки короткочерешкові, видовжені, на верхівці загострені, покриті жорсткими волосками. Верхні листки стебла майже сидячі.

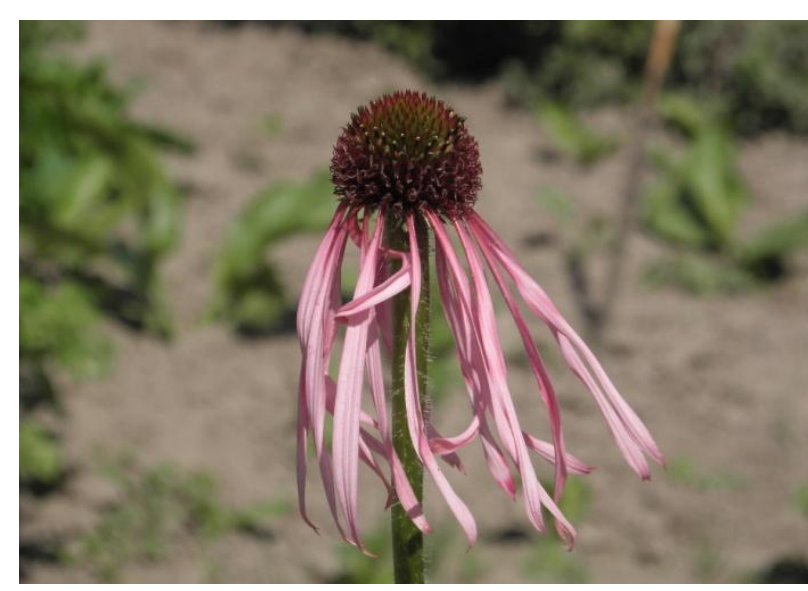

Рис. 2. Цвітіння E. pallida

E. paradoxa - єдина в роді жовта ехінацея. Рослини досягають висоти 75-100 см. Стебло та листки темно-зеленого кольору, пряме, ребристе. Прикореневі листки довгастоланцетні. Верхні листки короткочерешкові, майже сидячі. Темно-коричневі трубчасті квітки ехінацеї утворюють випуклу, майже круглу серединку, язичкові доволі сильно пониклі, майже обнімають пагін (рис. 3).

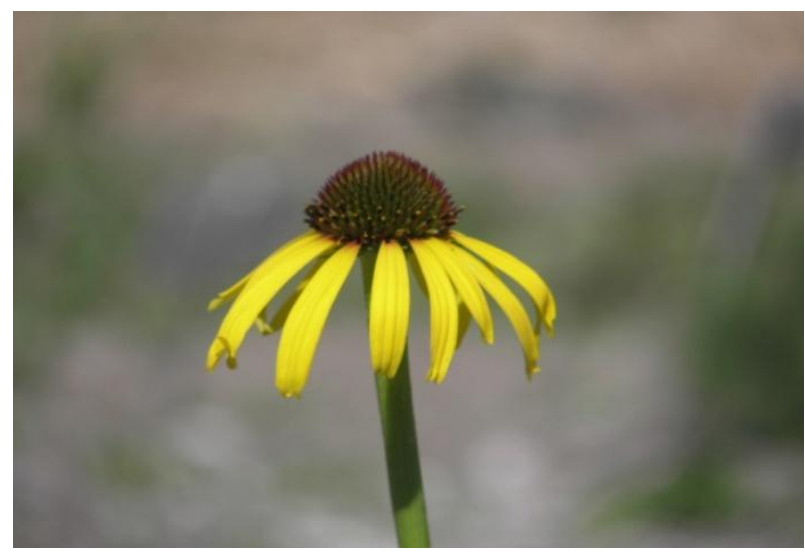

Рис. 3. Цвітіння E. Paradoxa

За розміщенням бруньок відновлення Echinacea T. А. Журавель (2000), відносить Ехінацеї до гемікриптофітів. За тривалістю циклу розвитку належать до багаторічних рослин із зимуючими моноциклічними пагонами. Види роду Echinacea відносять також до мезофітів, оскільки вони потребують середніх або високих кількостей вологи під час культивування.

При інтродукції в рослин змінюються ритм розвитку та морфологічні ознаки, що впливає на зміну їхньої життєвої форми. Процеси, які відбуваються в листках, визначають зв'язок із довкіллям. На думку І. Н. Пустинського (2000) на будову й форму вегетативних органів 
Дослідження морфологічних ознак видів роду Echinacea (L.) Moench. при інтродукиї в умови Кременеиького ботанічного саду

рослин впливає середовище, у якому вони зростають [7]. У зв'язку з цим нами досліджено морфологічні особливості листових пластинок і пагонів. Узагальнювальна інформація стосовно середніх значень кількісних морфоознак в особин третього року вегетації інтродукованих у КБС видів роду Echinacea Moench наведено в табл. 1.

Порівнюючи біометричні показники видів роду Echinacea, спостерігаємо, що молоді генеративні рослини E. paradoxa на третій рік вегетації мають меншу висоту та діаметр стебла, порівняно 3 іншими видами. Також спостерігаємо меншу кількість генеративних пагонів, що становить 4-6 шт. на рослину з 1 або 2 суцвіттями на пагоні, що можна пояснити видовими особливостями.

Нами проведено виміри форми листової пластинки та довжини черешка залежно від їх формації. Стеблові листки у видів розміщені почергово i ïx можна розділити на чотири листові формації: верхню, середню, нижню й базальну. Дані щодо морфології листкової пластини досліджуваних видів наведено в табл. 2.

Параметри листкових пластин указують на те, що листки базальної формації формують розетку $з$ довгочерешкових листків довжиною черешка до 20 і більше сантиметрів. Листки верхньої формації у видів майже сидячі або на коротеньких черешках від 1 до 1,28 см.

\section{Біометричні параметри пагонів представників роду Echinacea}

\begin{tabular}{|c|c|c|c|c|}
\hline Вид роду & $\begin{array}{c}\text { Віковий } \\
\text { стан }\end{array}$ & Довжина пагона, $\boldsymbol{M}$ & $\begin{array}{c}\text { Діаметр } \\
\text { пагона, } \boldsymbol{M м}\end{array}$ & $\begin{array}{c}\text { Кількість } \\
\text { генеративних } \\
\text { пагонів, } \text { ит. }\end{array}$ \\
\hline E.purpurea & $\mathrm{g}_{2}$ & $108 \pm 7$ & $8,3 \pm 1,6$ & $8,6 \pm 2,2$ \\
\hline E. pallida & $\mathrm{g}_{2}$ & $101,2 \pm 8,5$ & $8,2 \pm 2,4$ & $7,8 \pm 1,4$ \\
\hline E. paradoxa & $\mathrm{g}_{2}$ & $99,2 \pm 7,1$ & $7,03 \pm 1,2$ & $4,6 \pm 0,9$ \\
\hline
\end{tabular}

Таблиия 2

Морфологічні параметри листкової пластинки видів роду Echinacea

\begin{tabular}{|c|c|c|c|c|}
\hline \multicolumn{2}{|c|}{ Морфологічний параметр } & E. purpurea & E. pallida & E. paradoxa \\
\hline \multirow{3}{*}{$\begin{array}{c}\text { Нижня } \\
\text { формація } \\
\text { листків }\end{array}$} & $\begin{array}{c}\text { Довжина листкової } \\
\text { пластинки, } c м\end{array}$ & $15,3 \pm 3,4$ & $23,18 \pm 2,4$ & $18,96 \pm 1,8$ \\
\hline & $\begin{array}{c}\text { Ширина листкової } \\
\text { пластинки, } c м\end{array}$ & $4,8 \pm 0,7$ & $6,46 \pm 1,2$ & $2,92 \pm 0,3$ \\
\hline & Довжина черешка, $c м$ & $8,08 \pm 2,3$ & $6,9 \pm 1,5$ & $8,42 \pm 1,8$ \\
\hline \multirow{3}{*}{$\begin{array}{c}\text { Середня } \\
\text { формація } \\
\text { листків }\end{array}$} & $\begin{array}{c}\text { Довжина листкової } \\
\text { пластинки, } c м \\
\end{array}$ & $10,7 \pm 3,4$ & $19,35 \pm 1,4$ & $18,86 \pm 1,3$ \\
\hline & $\begin{array}{c}\text { Ширина листкової } \\
\text { пластинки, см }\end{array}$ & $4,8 \pm 0,6$ & $3,56 \pm 0,8$ & $3,04 \pm 0,5$ \\
\hline & Довжина черешка, $c м$ & $3,32 \pm 0,8$ & $2,48 \pm 1,2$ & $3,53 \pm 1,1$ \\
\hline \multirow{3}{*}{$\begin{array}{c}\text { Верхня } \\
\text { формація } \\
\text { листків }\end{array}$} & $\begin{array}{c}\text { Довжина листкової } \\
\text { пластинки, } c м\end{array}$ & $8,57 \pm 0,8$ & $10,08 \pm 1,7$ & $10,41 \pm 1,5$ \\
\hline & $\begin{array}{c}\text { Ширина листкової } \\
\text { пластинки, см } \\
\end{array}$ & $2,9 \pm 0,2$ & $1,72 \pm 0,3$ & $1,74 \pm 0,4$ \\
\hline & Довжина черешка, $c м$ & $1,28 \pm 0,5$ & $1,1 \pm 0,3$ & $1,12 \pm 0,5$ \\
\hline \multirow{3}{*}{$\begin{array}{l}\text { Базальні } \\
\text { листки }\end{array}$} & $\begin{array}{c}\text { Довжина листкової } \\
\text { пластинки, } c м\end{array}$ & $14,28 \pm 4,3$ & $25,43 \pm 2,1$ & $21,5 \pm 3,9$ \\
\hline & $\begin{array}{c}\text { Ширина листкової } \\
\text { пластинки, } c м\end{array}$ & $6,89 \pm 0,7$ & $5,78 \pm 1,2$ & $3,6 \pm 0,6$ \\
\hline & Довжина черешка, $c м$ & $21,72 \pm 2,9$ & $23,45 \pm 9,1$ & $18,07 \pm 5,4$ \\
\hline
\end{tabular}


Ширина листкових пластинок у нижній та середній формаціях для всіх видів суттєво не відрізняється. Дещо помітна різниця в довжині листків. Якщо для виду E. paradoxa довжина листкової пластинки нижньої формації становить 18,96 см, то у виду E. pallida. перевищує 23 см і більше. А середня та верхня формації листків відрізняються більшою довжиною для видів E. paradoxa й E. pallida. Це вказує на видову мінливість у рослин роду Echinacea за такими ознаками, як висота рослин, діаметр стебла, довжина черешка, параметри листкової пластини.

У перший рік рослини не утворюють генеративних пагонів. Узимку надземні органи багаторічних видів відмирають. Навесні другого року життя 3 бруньок відновлення відростають нові пагони. У подальші роки їх кількість збільшується й на 3-й рік вегетації може бути від 4 до 8 залежно від видової різноманітності. Перехід до генеративного періоду онтогенезу Echinacea супроводжуються утворенням i розвитком пагонів, на яких утворюються суцвіття кошики.

Найпершою в умовах Кременецького ботанічного саду зацвітає E. paradoxa та E. pallida, найпізніше - E. purpurea. Найдовше продовжує квітувати E. purpurea. Тривалість іiі цвітіння становить 108 діб. На одній рослині може розвиватися до 40 шт. суцвіть із масою одного квіткового кошика 3,78 г. Середня кількість суцвіть на один пагін - 3,6 шт. загальною масою 13,08 г. У період квітування в рослин виду E. paradoxa, у середньому, на рослину розвивається 7 шт. суцвіть. На одному пагоні утворюється 1,6 кошика масою 4,32 г.
Для виду E. pallida характерна середня кількість суцвіть до 10 шт. на рослину. На одному пагоні може утворюватися $2-5$ суцвіть 3 масою 10,95 г та загальною масою однісї рослини 42,5 г. (рис. 4).

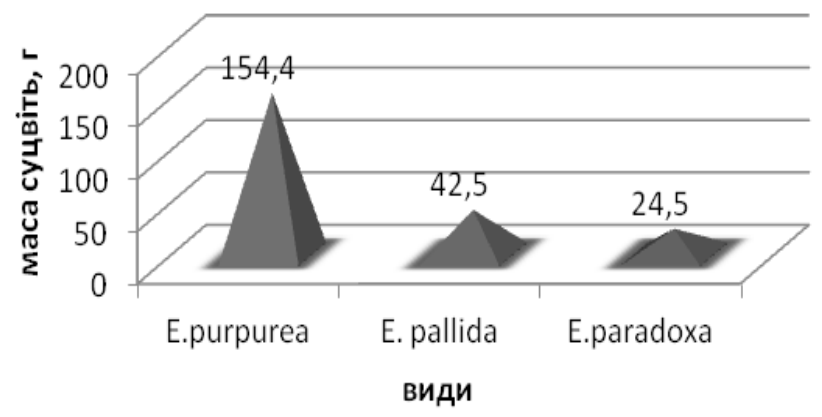

Рис. 4. Загальна маса суивіть на одну рослину

\section{Висновки}

В умовах інтродукції стадії цвітіння та плодоношення наступають у всіх досліджуваних видів на другий рік вегетації. Загальна маса суцвіть однієї рослини $E$. purpurea, яка становить 154,4 г, набагато перевищує ці показники у двох інших видів. Тривалість цвітіння двох інших видів менша, порівняно 3 E. Purpurea. Період їх розвитку більш скорочений i всі ростові процеси проходять інтенсивніше.

Проведений порівняльний аналіз морфологічних ознак підтверджує адаптаційну здатність досліджуваних видів до умов інтродукції в Кременецький ботанічний сад.

Таблиия 3

Біометрична характеристика суцвіть видів роду Echinacea залежно від видових особливостей

\begin{tabular}{|c|c|c|c|c|c|c|}
\hline Вид & $\begin{array}{c}\text { Поч./кін. } \\
\text { фази } \\
\text { цвітіння, } \\
\text { дата }\end{array}$ & $\begin{array}{c}\text { Тривалість } \\
\text { цвітіння, } \\
\text { діб }\end{array}$ & $\begin{array}{c}\text { К-сть } \\
\text { суцвіть, } \\
\text { шт. } \\
\text { /росл. }\end{array}$ & $\begin{array}{c}\text { К-сть } \\
\text { суцвіть, } \\
\text { ит./ } \\
\text { пагін }\end{array}$ & $\begin{array}{c}\text { Довжина } \\
\text { гол. } \\
\text { суцвіття, } \\
\text { см. }\end{array}$ & Колір \\
\hline E.purpurea & $\frac{25.06}{10.10}$ & $108 \pm 2$ & $39,8 \pm 1,3$ & $3,6 \pm 0,9$ & $12,4 \pm 0,4$ & $\begin{array}{c}\text { Темно- } \\
\text { пурпуровий }\end{array}$ \\
\hline E. pallida & $\frac{8.06}{23.08}$ & $73 \pm 2$ & $10,0 \pm 1,5$ & $4,0 \pm 2,1$ & $16,45 \pm 1,2$ & $\begin{array}{c}\text { Світло- } \\
\text { пурпуровий }\end{array}$ \\
\hline E.paradoxa & $\frac{5.06}{6.09}$ & $93 \pm 3$ & $7,0 \pm 1,6$ & $1,6 \pm 0,5$ & $12,8 \pm 1,8$ & Жовтий \\
\hline
\end{tabular}


Дослідження морфологічних ознак видів роду Echinacea (L.) Moench. при інтродукиї в умови Кременеиького ботанічного саду

\section{Література}

1. Артюшенко 3. Т.; Федоров, А. А. Атлас по описательной морфологии высших растений. Плод. Наука: Ленинград; 1986; с 392.

2. Деревинская, Т. И.; Крицкая, Т. В. Особенности индивидуального развития эхинацеи пурпурной в условиях Одессы. Тез. докл. четвертої міжнар. конф. 3 медичної ботаніки. Київ; 1997; c 397-398.

3. Журавель, Т. А. Биологические особенности Echinacea pallida (Nutt.) Nutt. первого года жизни в Донеиком ботаническом саду НАН Украины. Тез. VI молодежной конф. ботаников в Санкт-Петербурге (15-19 мая 2000 г.). Буслай: Санкт-Петербург; 2000; c 244

4. Зайцев, Г. Н. Математическая статистика в экспериментальной ботанике. Наука; Москва, 1984.

5. Зиман, С. М. та ін. Ілюстрований довідник 3 морфології квітникових рослин. Навч.-метод. посіб. Вид. друге. Фітосоціоцентр: Київ; 2012; с 176
6. Проект організації території Кременецького ботанічного саду. Затверджено Наказом Міністерства охорони навколишнього природного середовища України № 325 від 10.07.2006 р. Київ, 2004.

7. Пустынский, И. Н., Прохоров, В. Н. Универсальная энщиклопедия лекарственных растений, Махаон: Москва; 2000; с 179-181.

8. Міщенко, I. А., та ін. Ефективність органічного землеробства у лікарському рослинництві на прикладі Ехінацеї пурпурової другого року вирощування. Перспективні напрямки наукових досліджень лікарських та ефіроолоійних культур. Матеріали II Всеукр. наук.-прак. конф. молодих вчених Лубни (Березоточа, 20-21 лип. 2017 р.); ДСРЛ ІАП НААН; Комунальне вид.; Лубни, 2017; с163.

9. Самородов, В. Н.; Поспелов, С. В. Эхинацея в Украине: полувековой опьт интродукиии и воздельвания. Полтава: Верстка, 1999; с 52. 